\title{
Federal Reserve Bank of St. Louis Review, Annual Index, 2008
}

\section{JANUARY/FEBRUARY}

William Poole, "Thinking Like a Central Banker."

Rajdeep Sengupta and Craig P. Aubuchon, "The Microfinance Revolution: An Overview."

Daniel J. McDonald and Daniel L. Thornton, "A Primer on the Mortgage Market and Mortgage Finance."

Riccardo DiCecio, Kristie M. Engemann, Michael T. Owyang, and Christopher H. Wheeler, "Changing Trends in the Labor Force: A Survey."

\section{MARCH/APRIL}

"In Memoriam: Anatol 'Ted' Balbach, 1927-2007."

William Poole, "Market Bailouts and the 'Fed Put."'

Thomas A. Garrett, "Pandemic Economics: The 1918 Influenza and Its Modern-Day Implications."

Edward Nelson, "Friedman and Taylor on Monetary Policy Rules: A Comparison."

Kristie M. Engemann, Michael T. Owyang, and Sarah Zubairy, "A Primer on the Empirical Identification of Government Spending Shocks."

\section{MAY/JUNE, PART 1}

David C. Wheelock, "The Federal Response to Home Mortgage Distress: Lessons from the Great Depression.”

William T. Gavin and Geentanjali Pande, "FOMC Consensus Forecasts."
Patrick A. Pintus, "Laffer Traps and Monetary Policy."

William T. Gavin and Kevin L. Kliesen, "Forecasting Inflation and Output: Comparing Data-Rich Models with Simple Rules.”

\section{MAY/JUNE, PART 2}

Charles T. Carlstrom and Timothy S. Fuerst, "Inertial Taylor Rules: The Benefit of Signaling Future Policy.”

Mark A. Wynne, "Core Inflation: A Review of Some Conceptual Issues.”

Joseph E. Gagnon, "Inflation Regimes and Inflation Expectations.”

Song Han and Casey B. Mulligan, "Inflation and the Size of Government."

\section{JULY/AUGUST}

\author{
Monetary Policy Under Uncertainty \\ Lars E.O. Svensson and Noah Williams, \\ "Optimal Monetary Policy Under \\ Uncertainty: A Markov Jump-Linear- \\ Quadratic Approach.”
}

Athanasios Orphanides and Volker Wieland, "Economic Projections and Rules of Thumb for Monetary Policy."

Marek Jarociński and Frank R. Smets, "House Prices and the Stance of Monetary Policy."

James D. Hamilton, “Assessing Monetary Policy Effects Using Daily Federal Funds Futures Contracts."

John B. Taylor, Ben S. Bernanke, and William Poole, "Panel Discussion." 
Carl E. Walsh, "Announcements and the Role of Policy Guidance.”

William Poole, "Rules-of-Thumb for Guiding Monetary Policy.”

Commentaries by:

Timothy W. Cogley

Andrew T. Levin

Charles I. Plosser

Patrick Minford

Robert G. King

Stephen G. Cecchetti

Alec Chrystal

Kenneth N. Kuttner

Marvin Goodfriend

\section{SEPTEMBER/OCTOBER}

Michael D. Bordo and Anna J. Schwartz,

"Monetary Economic Research at the

St. Louis Fed During Ted Balbach's Tenure

as Research Director."

Kevin L. Kliesen, "Oil and the U.S.

Macroeconomy: An Update and a Simple

Forecasting Exercise."

Alistair Milne and Geoffrey Wood, "Banking Crisis Solutions Old and New."

Paul Mizen, "The Credit Crunch of 2007-2008:

A Discussion of the Background, Market

Reactions, and Policy Responses.”

\section{NOVEMBER/DECEMBER}

David C. Wheelock, "Changing the Rules: State Mortgage Foreclosure Moratoria During the Great Depression."

Matthew S. Chambers, Carlos Garriga, and Don Schlagenhauf, "Mortgage Innovation, Mortgage Choice, and Housing Decisions."

Christopher J. Neely and David E. Rapach, "Real Interest Rate Persistence: Evidence and Implications."

Emin M. Dinlersoz, Rubén Hernández-Murillo, Han Li, and Roger Sherman, "Drug Prices Under the Medicare Drug Discount Card Program.” 